Tomasz POLAŃSKI

(Kraków, UJ)

\title{
WALKA WSCHODU I ZACHODU W LITERATURZE GRECKIEJ OD HERODOTA DO PROKOPIUSZA Z GAZY
}

\section{MIT HERODOTEJSKI I NARODZINY MYŚLI O PODBOJU WSCHODU}

W napisanym z perspektywy kilkudziesięciu lat wojen z Persami historiozoficznym Prooimion do swojej Historii Herodot rysuje panoramę narastającego konfliktu. Jego ślady znajduje już w mitycznych opowieściach o wzajemnych porwaniach kobiet, Io, Europy, Medei i Heleny. Historie te opowiada Herodot $\mathrm{z}$ właściwym sobie humorem i błyskotliwością. Kiedy dochodzi do wojny trojańskiej ton staje się poważniejszy. Winą za wywołanie tej brzemiennej w dziejowe skutki wojny obarcza Greków:

„Twierdzą, że właśnie od tego czasu świat helleński był im zawsze wrogi. Persowie rządzą Azją wraz ze wszystkimi zamieszkującymi ją ludami, podczas gdy Europa i Azja, jak wierzą, tworzą dwa zupełnie różne światy. Tak więc sprawy te przedstawiają się wedlug Persów. Początków swojej nienawiści do Hellenów dopatrują się więc w zdobyciu Troi"'.

W ten sposób wojny perskie uzyskują w twórczości Herodota perspektywę mitologiczną. Ich bezpośrcdnią przyczyną jest wzrost imperium perskiego, który prowadzi nieuchronnie do starcia despotycznego imperializmu z broniącymi swojej wolności Grekami. Myśl o odwiecznym konflikcie Wschodu i Zachodu uczynil Herodot jednym z głównych składników swojej historiozofii. Historia Herodota w sposób nieporównywalny z żadnymi późniejszymi dziełami literatury greckicj upamiętniła zarówno heroizm obrońców wolności Hellady, jak i odwagę perskiego rycerstwa, co jest widoczne np. w pełnym patetycznego piękna opisie szarży i śmierci Mardoniosa ${ }^{2}$ lub Masistiosa ${ }^{3}$. Podobnie jak

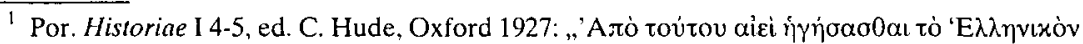

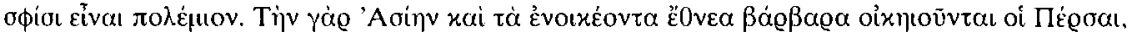

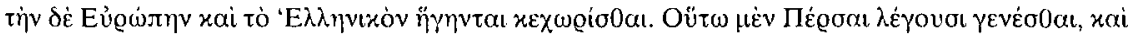

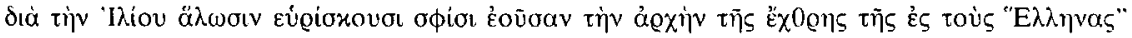
(przekład ten i następne - własny).

${ }^{2}$ Por. tamże IX 63.

3 Por, tamze IX 22. 
Homer, Herodot podziwial odwage walczących po obu stronach. W tym wymiarze był $w$ najlepszym tego słowa znaczeniu uczniem Homera. Żaden z pisarzy greckich nie osiągnął tego niezwykłego w swojej wielkoduszności uniwersalizmu, jaki cechował Homera i Herodota. I choć historiografię grecką wzorem Herodota, który stał się jej prawodawcą, wypełniają opisy kampanii wojennych, mowy i ekskursy etnograficzno-geograficzne, które kładą nacisk na niezwykłości przyrody Orientu i egzotykę świata jego mieszkańców wraz z ich obyczajami i religiami, to jednak w późniejszej historiografii rzadko można znaleźć charakterystyczną dla Herodota ciekawość świata i jego autentyczne zainteresowanie dziejami i kulturą Wschodu ${ }^{4}$. Herodota nazywano czasem nie bez nuty złośliwości $\phi\left(\lambda \circ \beta \alpha \dot{\varrho} \beta \alpha \varrho \varsigma^{5}\right.$. Przychodzi na myśl znane powiedzenie, że zrozumieć może tylko ten, kto kocha.

Niezwykłym zrządzeniem dziejów, wobec trwałości imperium perskiego, herodotejska teoria walki Wschodu i Zachodu stała się trwałym modelem opisu relacji pomiędzy ludami Iranu a Grekami. Napisana pod wrażeniem wzrostu potęgi imperium Achemenidów i militarnej konfrontacji z armiami perskimi teoria ta stanie się kiedyś ideologiczną podbudową konfliktu pomiędzy Macedonią Aleksandra Wielkiego a monarchią Dariusza III, a w dalszej perspektywie również wojen Rzymian z Arsakidami i Sassanidami. Miltiades, Temistokles i Leonidas z bohaterów lokalnej historii staną się z czasem bohaterami wszystkich Greków i Macedończyków, by wreszcie zrobić karierę w szkołach rzymskich, których uczniowie musieli zmagać się na Bliskim Wschodzie z dziedzicami Achemenidów. Herodot nie był twórcą tej osobliwej historycznej konstrukcji, która połączyła w jedno wojnę trojańską, stare baśnie greckie i wojny perskie $V$ wieku przed Chrystusem. Ale to on wypowiedział ją w sposób najpelniejszy. Jej początki zarysowują się w symetrycznym podziale świata na Europę i Azję jaki uwidocznił się już w geograficznym dziele Hekatajosa z Miletu ${ }^{6}$. Linia podziału

${ }^{4}$ Rolę przewodników po greckiej historiografii orientalistycznej moga pełnić następujące książki: R. Drews, The Greek Accounts of Eastern History, Cambridge 1973; K. Głombiowski, Ktezjasz z Knidos. Grecki historyk perskiej monarchii Achemenidow, Gdańsk 1981; L. Pearson. The Lost Histories of Alexander the Great, London 1960. Oceny rzeczywistej wiedzy Herodota na temat Iranu dokonał F. Thordarson, Herodotus and the Iranians, ,Symbolae Osloenses" 71 (1996) 42-58; tenże, Herodotus and the Iranians, tamże 72 (1997) 91-101. Herodot jako orientalista posiada swoją niemałą już biblioteczkę; oto niektóre znane i wartościowe studia: W. Spiegelberg, The Credibility of Herodotus' Account of Egypt in the Light of the Egyptian Monuments, Oxford 1927; A.B. Lloyd, Herodotus. Book II, vol. 1-3, Leiden 1975-1988; D. Fehling, Die Quellenangabe bei Herodot, Berlin 1971 (thum. ang. 1989); O.K. Armayor, Herodotus' Autopsy of the Fayoum: Lake Moeris and the Labyrinth of Egypt, Amsterdam 1985; S. West, Herodotus' Portrait of Hecataeus „Journal of Hellenic Studies” 111 (1991) 144-160.

${ }^{5}$ Por. Plutarchus, De Herodoti malignitate 857a.

${ }^{6}$ Por. G. Ceaușescu, Un topos de la littérature: l'éternelle guerre entre l'Europe et l'Asie "Latomus" 69 (1991) 327-341, spec. s. 329n.; również epoce wojen perskich V wieku prz. Chr. poświęcony jest artykut: R. Cantarella, La Persia nella letteratura greca, w: Atti del convegno sul tema: La Persia e il mondo greco-romano, Roma 1966, 489-504. 
przebiegała wzdłuż wód Hellespontu. Tę granicę światów miał kiedyś potwierdzić traktat pokojowy Antalkidasa (387 r. prz. Chr.), na mocy którego Persowie zobowiązywali się nie przekraczać ustalonej granicy Azji i Europy. Simonides z Keos nazywa Hellespont miejscem fatalnym, miejscem, gdzie rodzą się straszliwe wojny ${ }^{7}$. Trudno w to uwierzyć, stojąc wśród urzekająco pięknego krajobrazu cieśnin, jakby stworzonego dla bohaterów sielanki, dla Pana, czy Herony i Leandra. Z drugiej strony wspomnienie straszliwej bitwy na Galipoli z 1915 r., bitwy która pochłonęla ok. 100 tysięcy żołnierzy armii sprzymierzonych i ostatecznie zakończyła się klęską, może wywołać pytanie, czy Simonides czasem nie mial racji. W Persach Ajschylosa, powstałych kilkadziesiąt lat przed Historiq Herodota (472 r. prz. Chr.), Atossa opowiada swój sen: ujrzała dwie kobiety ubrane w strój perski i grecki, które Kserkses próbował zaprząc do swojego rydwanu; kobieta w doryckim peplosie broniła się rozpaczliwie, skruszyła jarzmo i doprowadziła do rozbicia rydwanu ${ }^{8}$. Niedługo po wystawieniu Persów twórcy dekoracji malarskiej Stoa Pojkile zestawili obok siebie Amazonomachię, Centauromachię i bitwę pod Maratonem ${ }^{9}$. Z czasem lokalny mit attycki stał się mitem Zachodu. Izokrates nawołując do wojny z Persami powoła się na przykład wojny trojańskiej, jako pierwszego zwycięstwa Europy nad Azją ${ }^{10}$. Lizjasz $^{11}$ i Platon ${ }^{12}$ widzieli już wojny grecko-perskie w kategoriach ataku perskiego na całą Europę ${ }^{13}$. Izokrates sięga do motywu wyższości Greków nad Persami ${ }^{14}$, motywu, który przeżywa znów renesans we współczesnej kulturze masowej Zachodu. Pompejusz Trogus wspomina dwa orły siedzące na dachu domu, w którym przyszedł na świat Aleksander Wielki; miały one symbolizować dwa kontynenty: Europę i Azję ${ }^{15}$. Po zwycięstwie pod Gaugamelą Aleksander postanawia odbudować Plateje w uznaniu zasług tych, którzy polegli w walce o wolność Hellady w latach 480-479. Podobnie w liście do Krotonu nawiązuje do bitwy pod Salaminą ${ }^{16}$. Ateńska hetera Tais namawia Aleksandra, aby spalił Persepolis z zemsty za spalenie Aten przez Kserksesa ${ }^{17}$. W stepach środkowej Azji, jak przystało na bohatera, który poszedł w ślady Heraklesa, Aleksander

\footnotetext{
${ }^{7}$ Por. Anthologia Palatina VII 296.

${ }^{8}$ Por, Persae 176-199.
}

${ }^{9}$ Por. C. Robert, Die Marathonschlacht in der Poikile und weiteres ïber Polygnot, Halle 1895; T. Hölscher, Griechische Historienbilder des 5. ınd 4. Jahrhunderts v. Chr., Würzburg 1973, spec. ss. 200-214; E. Harrison, The South Frieze of the Nike Temple and the Marathon Painting in the Painted Stoa ,American Journal of Archaeology” 76 (1972) 354-378.

${ }^{10}$ Por. Helene encomium 67; Panathenaicus 83; Archidamus 54.

11 Por. Epitaphius 21.

12 Por. Leges $698 \mathrm{~b}$.

13 Por.. Ceauşescu, art. cyt., s. 333, również przypisy 18, 19.

14 Por. Panathenaicus 47.

15 Por. Justinus, Historiae Philippicae XII 16.

16 Por. Plutarchus, Alexander 34,1.

17 Por. tamze 38. 
spotkał siç równicż z królową Amazonek, co utrwalił Oncsikritos ${ }^{18}$. Jeszcze wiele wieków później, gdy Ammianus Marcellinus będzie oglądał z ukrycia w Górach Gordiene przemarsz wojsk Chosroesa I, przypomni sobic paradę wojsk inwazyjnych Kserksesa w Doriskos ${ }^{19}$. Herodotejski mit, jak sic̨ miało okazać, krył równicż pewne niebczpieczeństwa. Alkajos z Messeny przeciwstawiał niewolę Kscrksesa wolności ofiarowanej Helladzie przez Flamininusa ${ }^{20}$. Alkajos mylił się oczywiście, jak wielu mu współczesnych, ponieważ Rzym nic przyniósł Hclladzic wolności, lecz nową, jeszcze cięższą od macedońskiej, nicwolę $^{21}$. Na koniec tych rozważań można by podkreślić, że Homer, który wśród Dardanów. Lyków, Sydończyków czy Egipcjan swojej epoki czuł się jak u sicbie, a w każdym razie jak u swoich dobrych sąsiadów, został wykorzystany na potrzeby propagandy wojennej w epoce klasycznej Grecji w sposób całkowicie anachroniczny i niczgodny ze swoimi intencjami. Wiele wieków późnicj tacy ludzie jak H. Schliemann sprawili, że mit Troi przybrał inny kształt. Stał się mitem romantycznej przygody i archeologii.

Znany nam z Historii Herodota świat Azji Zachodnicj, wyrosły na gruzach imperium asyryjskiego, dobiegł swego kresu wraz z wyprawą Aleksandra Wielkicgo. Grecy rozproszyli się na ogromnych obszarach od Myzji i Bitynii po Indus, od Pontu i stepów Azji Środkowej po Egipt i Zatokę Perską. Autorem niewiarygodnego pomysłu podboju Bliskiego i Środkowego Wschodu był niewątpliwie Aleksander Wielki, alc myśl o wielkiej wojnie Greków i Macedończyków z Persami dojrzewała już wcześniej w pismach przenikliwego obserwatora swojej epoki Izokratesa. Miał w niej swój udział również Ksenofont z Aten, który odkrył coś, co okazało się niezwykle ważne dla dalszego biegu stosunków grecko-orientalnych. W swojej barwnej opowieści o wyprawie 10 000 w Anabazie Ksenofont zebrał doświadczenia greckich najemników, którym udało się wtargnąć w głąb imperium perskiego, dotrzeć do Babilonu, i co ważniejszc, powrócić przez Armenię nad Morze Czarne. Plutarch podsumowal to zbiorowe, brzemienne w następstwa, greckie doświadczenie w następujących słowach:

..Wydostali się cali i zdrowi nieomal z samego królewskiego pałacu, przez co dowiedli w sposób niezbity, że Persowie i dwór królewski, choć mają pod dostatkiem złota, kobiet i wszelkiego bogactwa, tak naprawdę nic nic są warci. Stąd też cała Hellada nabrała odwagi i zaczęła pogardzać barbarzyńcami" ${ }^{22}$.

\footnotetext{
18 Por. tamże 46.

${ }^{14}$ Por. Res gestac XVIII 6, 23; Herodotus, Historiae VII 59-60.

20 Por. Anthologia Palatina XVI 5.

21 Por. J. Deininger, Der politische Widerstand gegen Rom in Griechenland 217-86 v. Chr.. Berlin - New York 1971: J.D. Gauger, Phlegon von Tralleis, mirab. III. Zu einem Dokument geistigen Widerstandes gegen Rom, .Chiron” 10 (1980) 225-261.






Aleksander Wielki z pewnością czytał Anabazę. Tak więc Ksenofont stał się chyba jednym z bardzo nielicznych greckich intelektualistów, którzy bezpośrednio wpłynęli na historię stosunków grecko-perskich. Może dlatego, że był prawdziwym awanturnikiem, zawodowym zołnierzem i wybitnym historykiem w jednej osobie.

\section{IDEA ZGODY NARODÓW ALEKSANDRA WIELKIEGO I JEJ DZIEDZICTWO W EPOCE HELLENISTYCZNO-RZYMSKIEJ}

Wśród wojen tej epoki natrafiamy na ślady refleksji tych, którzy próbowali przełamywać naturalne bariery miçdzy ludźmi mówiącymi zupełnie różnymi językami i wierzącymi w innych bogów. Plutarch zastanawia się, czy Aleksander przywdziewając persko-medyjską szatę chciał rzeczywiście sam przyjąć miejscowe obyczaje, ponieważ wiedzial, żc żyjąc zgodnie z nimi pozyska sobic przyjaźn perskiej arystokracji, czy też może, jak podejrzewał autor jego biografii, Aleksander usiłował przyzwyczaić Macedończyków do orientalnego obyczaju upadania na twarz przed królem:

„Najpierw więc ubral barbarzyńską szatę. Być może chciał przystosować się do miejscowych obyczajów. Wszak wiemy, że przez naśladowanie obyczajów narodowych najprędzej można pozyskać sobie ludzi. Niewykluczone również, że próbował przyzwyczaić Macedończyków do obyczaju padania przed nim na twarz" ${ }^{23}$.

Możemy być chyba pewni, że Aleksander chcial jednak tego pierwszego. Plutarch powtarza również za historykami Aleksandra, że zachowaniem swoim król oswajal z miejscowymi obyczajami wszystkich Macedończyków, wiedząc, że poprzez wzajemne zbliżenic, współpracę i dobrą wolę więcej osiągnie niż siłą ${ }^{24}$. Jednym ze sprawdzianów szczerości jego intencji był ślub z Roksaną, księżniczką Roszanak, który zyskał mu sympatię jego perskich poddanych:

„Małżeństwo to sprawilo, że barbarzyńcy poczuli się pewnicj w towarzystwie Macedończyków"25.

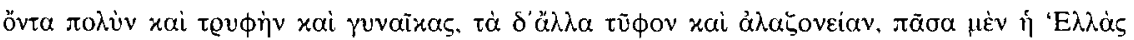

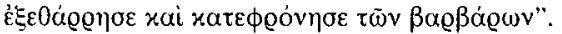

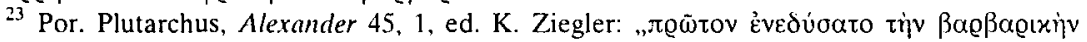

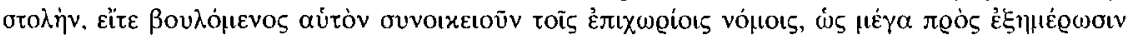

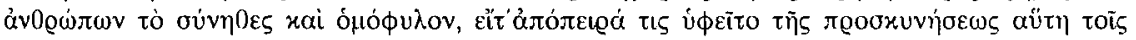
Maxedóoi".

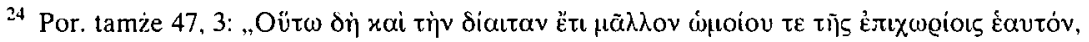



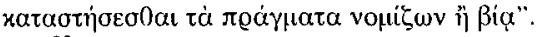

25 Tamie $47,4$. 
Te próby pośrednictwa rodziły czasem przedziwne owoce. Wraz z Aleksandrem udał się na Wschód cynik Onesikritos. Odkrywał on raz po raz, że naukę Diogenesa i Antisthenesa wiele łączy z poglądami Brahmanów i filozofów buddyjskich. Inspiracja ta długo przetrwała w literaturze greckiej. Wiele stuleci później w jakiejś mierze właśnie pod wpływem indyjskiej filozofii, Peregrinus dokonał z kamiennym spokojem samounicestwienia w płomieniach podczas igrzysk olimpijskich w 165 roku $^{26}$. Wzorem dla niego był sławny gymnosofista Kalanos, który spalił się przed obliczem Aleksandra, gdzieś na obszarach współczesnego Pakistanu ${ }^{27}$. Samobójcza śmierć Peregrinusa w Olimpii miała chronologiczny związek ze stłumionym krwawo antyrzymskim powstaniem na Peloponezie ${ }^{28}$. Historia ta kojarzy się z wstrząsającymi filmami, ukazującymi akty samospalenia mnichów buddyjskich w południowym Wietnamie w proteście przeciw niszczeniu świątyń i prześladowaniu religii.

Plutarch zauważył jednocześnie, że niekiedy spotkania różnych kultur mogą przynosić owoce hybrydalne. W swoim żywocie Krassusa opisał ucztę armeńskiej i perskiej arystokracji, podczas której greccy aktorzy recytowali $B a$ chantki Eurypidesa. W pewnej chwili do komnaty wszedł poseł i rzucil przed zebranych skrwawioną głowę Krassusa, a wtedy aktor Jazon z Tralleis zmienil strój i zacząl recytować wstrząsającą pieśń obłąkanej Agaue, która przynosi z Kithajronu nabitą na tyrs głowę własnego syna ${ }^{29}$.

Jeszcze jedną próbę budowania pomostów w kosmopolitycznej epoce helIenizmu podjęła grupa żydowskich pisarzy aleksandryjskich, aby oswoić swoich pobratymców z kulturą helleńską. Gdyby nie naukowa sumienność Euzebiusza z Cezarei prawdopodobnie nic byśmy o nich nie wiedzieli ${ }^{30}$. Odrzuceni przez swoich, zlekceważeni przez obcych, zostali zapomniani. Epoka hellenistyczna przynosi również pisma historyczne, które można by określić jako nurt filorientalizmu w literaturze greckiej. Świadectwa na ten temat zebrał Diodor w pierwszych dwóch księgach swojej Biblioteki ${ }^{31}$. Cytuje on w niej obszerne fragmenty

${ }^{26}$ Por. Lucianus, De morte Peregrini; Ch. Jones, Cynisme et sagesse barbare: Le cas de Pérégrinus Proteus, w: M.O. Goulet-Cazé - R.Goulet (red.), Le cynisme ancien et ses prolongements. Paris 1993, 305-317; H. Hornsby, The Cynicism of Peregrinus Proteus, „Hermathena” 48 (1933) $65-$ 84; M.O. Goulet, ANRW II 36, 4. Berlin 1960, 2764-2767; J. Filliozat, L'abandon de la vie par le sage et les suicides du criminel et du héros dans la tradition indienne, „Arts Asiatiques” 85 (1967) 65-88.

27 Por. Plutarchus, Alexander 69.

28 Por. Historia Augusta. Pius 5, 5.

29 Por. Plutarchus, Crassus 32, 3-5.

${ }^{30}$ Artapanos, Aristobulos, Eupolemos, Ezechiel i in.; por. J. Giblet, Eupolème et l'historiographie du Judaisme hellénistique, EthL 39 (1963) 539-554; W. Speyer, Die literarische Fälschung im heidnischen und christlichen Altertum, München 1972, 152nn; J. Wienecke (rec.), Ezechielis Iudaei poetae Alexandrini fabulae quae inscribitur E $\Xi A \Gamma O \Gamma H$ fragmenta, Monasterii 1931; zob. jej polski przekład R. Sawy: Ezechiel Tragik, Wyprowadzenie, VoxP 10 (1990) 2. 19, 867-884.

31 Por. A. Burton, Diodorus Siculus. Book I. A Commentary, Leiden 1972; E. Murphy, The Antiquities of Asia. A Translation with Notes of Book II of the Library of History of Diodorus 
wielkiego entuzjasty kultury egipskiej Hekatajosa z Abdery, jednego z dworskich pisarzy Ptolemeusza II Filadelfa, zauwazając również, że Chaldejczycy stworzyli solidną wiedzę dzięki stałości i konsekwencji swoich przekonań, podczas gdy Grecy w swojej bezustannej pogoni za zyskiem tworzą coraz to nowe szkoły filozoficzne, pogrążone w bezustannych konfliktach, co owocuje stanem chaosu i zamętu w umysłach młodzieży i ostatecznie przez całe życie ${ }^{32}$.

Myśl o pojednaniu Wschodu i Zachodu powracała więc wielokrotnie w historii kultury grecko-rzymskiej, mimo iż kolejne krwawe konflikty obracały ją w utopię. Powrócila również w interesującym pomyśle Dioklecjana, który polecił wybudować na Wyspie File w Górnym Egipcie świątynię Ozyrysowi i Izydzie, w której to świątyni służbę sprawować mieli kapłani zarówno rzymscy jak i miejscowi. Dioklecjan wierzył, że przez wspólnotę kultów religijnych zdoła pojednać walczących ze soba Blemmjów, Nabatów, Egipcjan i Rzymian. Świątynia ta, jak opowiada nam Prokopiusz z Cezarei, została zamknięta na rozkaz Narsesa, a jej posągi odesłano do Bizancjum ${ }^{33}$. Theophylactos Symokatta przytacza list Chosroesa II (590-628) do Maurycjusza, którego autor charakteryzuje dwa wielkie imperia - perskie i rzymskie - jako fundament światowego porządku $z$ woli boskiej opatrzności ${ }^{34}$. Tak więc po stuleciach konfliktów pojawia się w historiografii greckiej myśl o charakterze uniwersalnym, wypowiedziana być może pod wpływem poczucia narastającego zagrożenia, zagrożenia, którego skala przekraczała ramy konfliktów regionalnych. Ciekawe, że myśl ta pojawia się dopiero w przeddzień dziejowej katastrofy, która dotknęła jednocześnie świat rzymsko-grecki i irański, ale byly to już inne czasy. Ówczesny Bliski Wschód ulegał stopniowej chrystianizacji. Drakoncjusz pozostawił nam obraz Piotra Apostoła blogosławiącego zgodzie Europy i Az$\mathrm{ji}^{35}$. Tej kolejnej optymistycznej wizji zaprzeczył po raz kolejny podzial Kościołów chrześcijańskich na Wschodzie, który zapadł na stulecia wzdłuż granic językowych: Kościoły syryjski, egipski, etiopski czy ormiański wybrały własną drogę rozwoju, w środowisku wlasnego języka narodowego i własnej kultury, odrzuciwszy język grecki i kulturę hellenizmu.

Wyprawa Aleksandra stanie się trwałym elementem myślenia o Wschodzie w historiografii greckiej, ale także w greckiej i rzymskiej polityce wschodniej,

Siculus, New Brunswick 1989; tenże, The Antiquities of Egypt. A translation with notes of Book of the Library of History of Diodorus Siculus, New Brunswick N.J. 1990.

${ }^{32}$ Por. Bibliotheca II 29, 6.

${ }^{33}$ Por. Historia bellorum. Persica I 19; P. Nautin, La conversion du temple de Philae en Église chrétienne, „Cahiers Archéologiques” 17 (1967) 1-43.

${ }^{34}$ Por. Historiae IV 11; okresowi temu poświęcony jest artykuł A. Pertusi, La Persia nelle fonti bizantine del secolo VII, w: Atti del convegno internazionale sul tema: La Persia nel medioevo, Roma 1970, 605-632; a także: G. Carratelli, La Persia dei Sassanidi nella storiografia romana da Ammiano a Procopio, tamże, ss. 597-604.

${ }^{35}$ Por. Laudes Dei III 230. 
a nawet w wojskowości. Pamięć o niej utrzyma się w świecie klasycznym przez długie stulecia. Przetrwa niepowodzenia i klęski. I właściwie trudno się temu dziwić. Wszak swoją obecność w Syrii, Egipcie czy nawet w Babilonii, jako uprzywilejowanej klasy administratorów i właścicieli, zawdzięczali Grecy Aleksandrowi. Szlakiem Aleksandra wyruszy później m.in. Krassus. Jego niespodziewana klęska i śmierć pod Carrhae (Harran) (53 r. prz. Chr.), obecnie nad samą granicą turecko-iracką, odegrała w refleksji historycznej Greków i Rzymian rolę podobną, jak klęska w Lesie Teutoburskim ( 9 r. po Chrystusie). I jak się miało okazać, bitwa pod Carrhae na trwale wyznaczyła granicę zasięgu imperium rzymskiego na Wschodzie. Carrhae i mierzący z łuków jeźdźcy perscy stali się prawdziwym kompleksem literatury rzymskiej, co pokazał na wielu przykładach E. Paratore w obszernym artykule La Persia nella letteratura latina ${ }^{36}$. Plutarch zachował przejmujący opis pustyń noszący wszelkie znamiona autentyczności, opis przekazany przypuszczalnie przez któregoś z ocalałych z pogromu żołnierzy Krassusa:

„Na początku droga była prosta i wygodna, potem już tylko trudna. Nogi zapadaty się głçboko w piachu, a wokół ciągnęły się bezdrzewne, bezwodne i bezkresne równiny, na których nie było na czym oprzeć oczu. Nic tylko pragnienie i trudy marszu powodowały wyczerpanie, lecz przede wszystkim bezkres wywołujący niemoźliwe do wypowiedzenia przygnębienie $w$ duszach żołnierzy. Nie znajdowali na równinach żadnej rośliny, żadnego strumienia, żadnego górskiego grzbietu, żadnej zieleniejącej trawy. Widać było jedynie pofalowane wydmami bezkresne morze pustyni" ${ }^{37}$.

Podjęte w II wieku po Chr. przez Trajana, Marka Aureliusza i Septymiusza Sewera nowe wojny na Bliskim Wschodzie, przyniosą renesans zainteresowań wojnami grecko-perskimi i wyprawą Aleksandra. Swoją rolę odegra tu również związany z nurtem Il sofistyki zwrot ku przeszłości klasycznej. Świadectwem tych zainteresowań jest Anabaza Flawiusza Arriana, wzorowana na Anabazie Ksenofonta, poczytny Romans Aleksandra, który w epoce wypraw krzyżowych w łacińskiej wersji zawędrowal aż do Krakowa, mowy Polemona na cześć bohaterów poległych pod Maratonem, czy ekfraza Alexander sive Aetion Lukiana $\mathrm{z}$ Samosate ${ }^{38}$. Również $\mathrm{w}$ tej epoce pojawiła się literatura nowojońska wzoro-

${ }^{36}$ Por. E. Paratore, La Persia nella letteratura latina, w: Atti del convegno sul tema: La Persiae il mondo greco-romano, Roma 1966, 505-558.

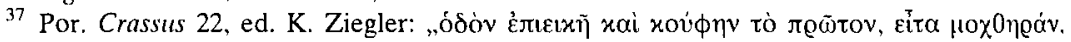

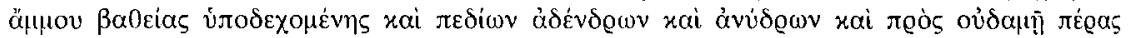

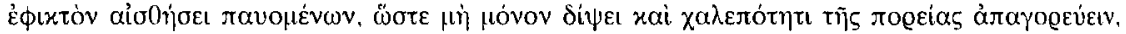





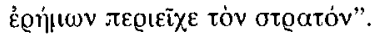

${ }^{36}$ Por. P. Stadter, Flovitus Arrianus: the New Xenophon, „Greek, Roman and Byzantinian Studies" 8 (1967) 155-161; E. Budge, The History of Alexander the Great being the Syriac Version of the Ps. Callisthenes, Cambridge 1889; R. Merkelbach, Die Quellen der griechischen Alexanderro- 
wana na stylu Herodota. Jej świadectwami są Indica Arriana czy Dea Syria ze zbioru pism Lukiana z Samosate ${ }^{39}$. Trajan stając nad wybrzeżami Zatoki Perskiej przypomni Aleksandra Wielkiego. Za swoje efemeryczne zdobycze, które nie przetrwają zdobywcy, zapłaci życiem. Kilkadziesiąt lat później legiony Marka Aureliusza zajmą Ktezyfont, ale zdziesiątkowane zarazą będą musiały cofnąć się za Eufrat. Przez następne kilkanaście lat przywleczona przez rzymską armię ze Wschodu dżuma będzie szalała w granicach całego Imperium. Jest rzeczą interesującą, że nie zachował się żaden zapis tych działań wojennych. Posiadamy jedynie krytykę dzieł historyków tej wojny pióra Lukiana z Samosate, który określa je jako rzekomo nieadekwatne wobec wielkości zwycięstw rzymskich. Lukian atakuje również ich styl, jego zdaniem, odbiegający daleko od poziomu narracji historycznej Tukidydesa. Mam tu na myśli utrzymane w pretensjonalnym, dworskim stylu pismo Lukiana Quomodo historia conscribenda sit. Przy calym swoim talencie retora i pisarza, Lukian nie staral się zrozumieć historii politycznej i militarnej. Pisma historyków Marka Aureliusza, ocenione przez niego z perspektywy klasycystycznych standardów II sofistyki, zostały skazane na zapomnienie. Można tylko wyrazić żal, że nie przetrwaly. W kategoriach manii Kasjusz Dion opisal kult, jaki żywił dla Aleksandra Wielkiego Karakal$\mathrm{la}^{40}$, który pijał z kubków Aleksandra, hodował słonie, prześladował arystotelików, ponieważ twierdził, że to Arystoteles był winien śmierci ubóstwianego władcy Macedończyków; w liście zaś do senatu wyjaśniał, że to on Karakalla jest wcieleniem Aleksandra, którego krótki żywot znalazł w nim swoje dopełnienie. Chęć odzyskania nietrwałych zdobyczy swojego wojowniczego ojca w Mezopotamii Karakalla przypłacil życiem. Jego następcę Heliogabala Kasjusz Dion nazywa Sardanapalem, pisząc z odrazą o jego orientalnych obyczajach, strojach i praktykach religijnych ${ }^{41}$. Ostatni przedstawiciel rodziny Sewerów z podobnych powodów, co jego kuzyni, dołączył do swojego oficjalnego imienia przydomek „Aleksander", i jest znany historii współczesnej pod imieniem Aleksander Sewer. Jeśli jeszcze przypomnieć poniżającą majestat Rzymu niewolę i śmierć Waleriana na dworze Szapura I (240-272), o czym wzmiankę zachował autor Historia Augusta ${ }^{42}$, śmierć Juliana i upokarzający odwrót Jowiana, których

mans, Monachium 1954; Polemo, Declamationes (Callimachus, Cynegirus), ed. H. Hinck, Leipzig 1873.

39 Por. F. Allinson, Pseudo-Ionism in the Second Century A.D., „American Journal of Philology" 7 (1886) 203-217; J. Garstang - H. Strong, The Syrian Goddess, Being a Translation of Lucian's De Dea Syria', London 1913; C. Clemen, Lukians Schrift iiber die Syrische Göttin übersetzı und erläutert, Leipzig 1937; H. Stocks, Studien zu Lukians 'De Syria Dea', „Berytus” 4 (1937) 1-40; R. Oden, Studies in Lucian's De Syria Dea', Missoula 1977; M. Horig, Dea Syria, NeukirchenVluyn 1979; J.L. Lightfoot, Lucian on the Syrian Goddess, Oxford 2003 (tekst, thumaczenie, komentarz).

40) Por. Historia Romana LXXVIII 6, 7.

4 Por, tamże LXXVIII 6, 30.

42 Por. Historia Augusta, Valerius 1-4. 
pamięć w swojej szczegółowej relacji ocalił piszący po łacinie Grek Ammianus Marcellinus $^{43}$, a wreszcie zmagania z Chosroesem I (531-579) wojsk rzymskich, które nie były w stanie zapobiec zdobyciu i złupieniu Antiochii, co z kolei w swoich naznaczonych goryczą przegranej Persikach opisal Prokopiusz z Cezarei $^{44}$, to można dojść do wniosku, że w dhugotrwałym biegu historii ten obszerny korytarz pomiędzy pustyniami współczesnej Syrii, Jordanii i Arabii Saudyjskiej a Wyżynami Iranu, w historii sprawnych i zaawansowanych technicznie armii rzymskich, odegrał rolę tunelu śmierci. Pisząc o wojnach w Górnej Mezopotamii w 2. poł. IV wieku Ammianus Marcellinus rozwiązuje niektóre hasła rzymskiego szyfru wojskowego: Granikos oznacza lokalną rzekę Anzaba, słowo Grecja, odczytywane jest jako Cesarstwo, przekroczenie zaś Hellespontu to kod rozpoczęcia wojny $z$ Rzymem ${ }^{45}$.

\section{MILITARYZM RZYMSKI WOBEC ASPIRACJI NARODÓW WSCHODU W EPOCE KONFRONTACJI Z IRANEM}

Jan Ksyfilin ocalił niezwykle cenny fragment z zaginionej części Historii Rzymu Kasjusza Diona, dotyczący przejęcia władzy w Iranie przez pierwszego z Sassanidów na tronie perskim - Ardaszira, oraz ocenę tego faktu z perspektywy rzymskiej:

„Ardaszir stał się dla nas groźny, ponieważ posiadając wielką armię zagrażał nie tylko Mezopotamii i Syrii, lecz jednocześnie zapowiadał, iż odzyska wszystko co mu się należy po przodkach, a więc wszystkie ziemie aż po Morze Egejskie, którymi kiedyś whadali Persowie. Pogróżki te same w sobie nie byłyby groźne, gdyby nie fakt, że wojska nasze byly tak zdemoralizowane, że albo sklaniały się ku Persom, albo w ogóle nie chciały stawiać oporu"46.

Zwracają uwagę ostatnie słowa, które świadczą o trudnościach utrzymania w posłuszeństwie wobec Rzymu rodzimej ludności wschodnich prowincji Cesarstwa. Ludność ta w niewielkim tylko procencie pochodzenia irańskiego, w zdecydowanej części semicka, szczególnie w okresie kryzysów ujawniała swoje sympatie wobec władców Iranu dopatrując się w nich alternatywy wobec

\footnotetext{
${ }^{43}$ Por. Res gestae XXV 3-7.

44 Por. Historia bellorum. Persica II 7-9.

45 Por. Res gestae XVIII 6, 18.

${ }^{46}$ Por. Historia Romana LXXX 3, 4, ed. V. Boissevain (Berlin 1895-1913): „ỡtós $\tau \varepsilon$ oưv

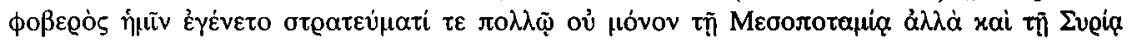

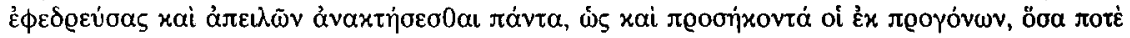

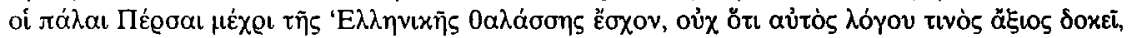

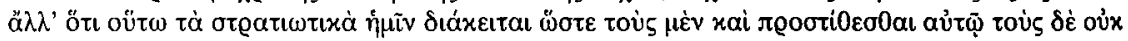

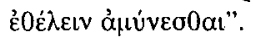


greckojęzycznej administracji rzymskiej. Dwieście lat później Prokopiusz z Cezarei przekazuje, że po kapitulacji garnizonu rzymskiego w syryjskiej Beroi większość jej mieszkańców odeszła z wojskami Chosroesa I (531$579)^{47}$. Sformułowany w kontekście konfliktów z Blemmjami i Nobatami pogląd Prokopiusza $z$ Cezarei na temat istoty stosunków Rzymu z barbarzyńcami, stanowi cenny aneks do herodotejskiej teorii walki Europy z Azją w jej ksztalcie hellenistyczno-rzymskim:

„Istnieje tylko jeden sposób zapewnienia sobie lojalności barbarzyńców - strach przed potęgą militarną Rzymu" ${ }^{48}$.

Prokopiusz nie doczekał się wydarzeń, które z całą jasnością ukazały to, do czego ostatecznie prowadzi mentalność kolonialna w stosunkach z ludami Wschodu, mentalność którą podzielało wielu Greków, już w epoce klasycznej ${ }^{49}$, a także, jakie skutki przynosi myślenie w kategoriach czysto militarnych. Po klęsce Herakliusza w bitwie nad rzeką Jarmuk w lipcu 638 r., Syryjczycy i Egipcjanie nie stawiając oporu pożegnali Greków i zaakceptowali panowanie arabskie. Może więc mają rację ci, którzy twierdzą, że fenomen odrodzenia języków i kultury syryjskiej i egipskiej w III wieku ma swoje źródła również $w$ osłabieniu władzy rzymskiej na tych terenach $w$ okresie wielkiego kryzysu Cesarstwa.

Zacytowany wyżej fragment z Historii Kasjusza Diona zawiera jeszcze jeden istotny element: perską antytezę klasycznej teorii konfliktu Wschodu i Zachodu. Tak jak Rzymianie odwoływali się do zwycięstw w wojnach grecko-perskich V wieku przed Chr. oraz do wyprawy Aleksandra, tak Ardaszir i Szapur I (240 - ok. 272) przywoływali dziedzictwo Achemenidów i czynili $\mathrm{z}$ niego program swojego panowania - odzyskanie dawnych prowincji perskich do Hellespontu. Licznie zachowane grecko-orientalne pisma profetyczne świadczą wyraźnie, że grecko-rzymska teoria walki Wschodu z Zachodem posiadała swoje orientalne alter ego. Ta zachowana w znacznej części w języku greckim anonimowa literatura, uzupełnia milczenie i wyniosłą izolację wielkich dzieł literatury antyku grecko-rzymskiego. Ocaliła ona zarazem coś z rzeczywistej motywacji, leżącej u podloża antygreckich i antyrzymskich buntów na Bliskim Wschodzie. Oracula Sibyllina - dzieła anonimowych autorów egipskich, żydowskich i syryjskich, pogan i chrześcijan - zostały zredagowane w XIV księgach w późnym antyku. Odnoszą się one do wydarzeń historycznych $\mathrm{z}$ okresu obejmującego od II wieku przed do VII po Chrystusie ${ }^{50}$.

${ }^{47}$ Por. Historia bellorum. Persica I 7, 27.

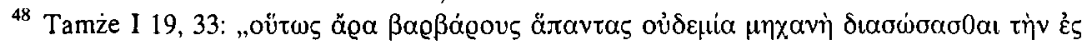

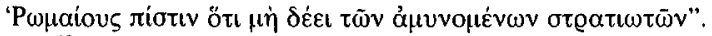

${ }^{49}$ Por. Pseudo-Arystoteles, Oeconomica II 1, 7.

${ }^{50}$ Por. Oracula Sibyllina, ed. J. Geffcken, GCS 8, Leipzig 1902; J.J. Collins, The Sybilline Oracles of Egyptian Judaism, Missoula 1974; A. Peretti, La Sibilla babilonese nella propaganda 
W swojej pojawiającej się już w Księdze Daniela wizji następstwa królestw, Oracula Sibyllina zapowiadają upadek potęgi Macedończyków i Rzymian oraz ostateczny tryumf ludów Wschodu ${ }^{51}$. Oracula Sibyllina były, jak ukazuje to w swojej książce $\mathrm{H}$. Fuchs ${ }^{52}$, prawdziwym orężem Wschodu w walce $\mathrm{z}$ Zachodem. Miały one swój odpowiednik w postaci greckojęzycznej profetycznej literatury Egiptu z czasów wojny partyzanckiej przeciw Macedończykom w II wieku prz. Chrystusem. Egipska apokaliptyka tej epoki nawiązuje do dawnych wzorów demotycznych sięgających okresu Nowego Państwa ${ }^{53}$. Flegon z Tralleis, jeden $\mathrm{z}$ historyków Hadriana, przytacza za Antisthenesem z Rodos wizję upadku Rzymu, zawartą w proroctwach Buplagosa, poległego pod Termopilami oficera Antiocha III (191 r. prz. Chr.), a następnie serię przepowiedni, jakie wygłosił w przedśmiertnym natchnieniu rzymski oficer Publiusz (Scypion Afrykański?). Są to wizje wojny, rabunku i niewoli, jakie przyniosą na Zachód wojska Wschodu ${ }^{54}$. Podobnie jak Antioch III, Oracula Sibyllina wykorzystywał w propagandzie wojennej przeciw Rzymowi również Mitrydates VI (121$63)^{55}$. Z kolei Laktancjusz zachował fragment irańskiej przepowiedni Hystaspesa: „Władza wróci do Azji, Wschód znowu będzie panował, a Zachód będzie mu służył" ${ }^{\prime 56}$. Wiemy o wielokrotnie podejmowanych urzędowych próbach

ellenistica, Firenze 1943; Sibyllinische Weissagungen, Urtext und Übersetzung, ed. A. Kurfess, München 1951; D.S. Russell, The Method and Message of Jewish Apocalyptic 200 BC-AD 200, London 1964; V. Nikiprowetzky, La troisième Sibylle, Paris 1970.

51 Por. Oracula Sibyllina III 171-195; 350-361; VIII 37-49; J.W. Swain, The Theory of the Four Monarchies. Opposition History under the Roman Empire, „Classical Philology” 35 (1940) 1-21.

52 Der geistige Widerstand gegen Rom, Berlin 1938, repr. Darmstadt 1964.

53 Por. F. Dunand, L'oracle du potier et la formation de l'apocalyptique en Égypte, w: L'Apocalypique. Études des l'histoire des religions, III, ed. M. Philonenko - M. Simon, Paris 1977, 41-67; J. Bergman, Introductory Remarks on Apocalypticism in Egypt, w: D. Hellholm, Apocalypticism in the Mediterranean World and the Near East, w: Proceedings of the International Colloquium on Apocalypticism (Uppsala 1979), Tübingen 1983, 51-60; tamże: M. Krause, Die literarischen Gattungen der Apokalypsen von Nag Hammadi, ss. 621-637; L. Koenen, Die Prophezeiungen des Töpfers, „Zeitschrift für Papyrologie und Epigraphik" 2 (1968) 178-209; Corpus Hermeticum II. Asclepius, ed. A.D. Nock - A.J. Festugière, Paris 1973; Nag Hammadi Codices, V 2-5 and VI, ed. D. Parrot, w: Nag Hammadi Studies XI, ed. M. Krause - J. Robinson - F. Wisse, Leiden 1979. O wojnie domowej w Egipcie Lagidów, zob. C. Préaux, Esquisse d'une histoire des révolutions égyptiennes sous les Lagides, „Chronique d'Égypte” 22 (1936) 522-552; M. Alliot, La Thébaide en lutte contre les rois d'Alexandrie sous Philopator et Épiphanes (216-184), „Revue Belge


scher Gegenkönig in Ägypten (132/1), „Chronique d'Égypte” 34 (1959) 103-119; T. Polański, Oriens militans: Extreme Traditionalist Movements in the Provincial Populace of the Ptolemaic Egypt and their Ideology. „Studies in Ancient Art and Civilisation” 9 (1999) 23-48.

${ }^{54}$ Por. F. Jacoby (ed.), Die Fragmente der griechischen Historiker, Leiden 1923-1958, 2b, 257 F.26.

55 Por. H. Fuchs, Der geistige Widerstand gegen Rom, Berlin 1938.

56 Divinae Institutiones VII 15, 11, CSEL 19, 632: „Imperium in Asiam revertetur ac rursus Oriens dominabitur atque Occidens serviet"; H. Windisch, Die Orakel des Hystaspes, Amsterdam 
zniszczenia orientalnej literatury profetycznej w okresie Cesarstwa ${ }^{57}$. Zmagają się z nią urzędnicy, pomagają im intelektualiści, jak Lukian z Samosate, który szydzi z Oracula Sibyllina ${ }^{58}$; najwyraźniej jednak bezskutecznie. Dostępną nam dokumentację tej walki zebral W. Speyer w swojej znakomitej książce Büchervernichtung und Zensur des Geistes bei Heiden, Juden und Christen (1981). Prawdopodobnie w odpowiedzi na wpływową i popularną literaturę profetyczną Bliskiego Wschodu, w której walka Europy z Azją należy do najczęściej spotykanych motywów, rodzą się podobne utwory w literaturze Zachodu. Podczas pobytu Aleksandra Wielkiego w Lykii, w okolicach Ksanthos rzeka wyrzuca ze swoich głębin starożytną przepowiednię dotyczącą upadku imperium perskiego ${ }^{59}$. Likofron $w$ swoim mrocznym i trudno zrozumiałym bez pomocy scholiów poemacie, imituje styl przepowiedni sybillińskich, a jednocześnie odwołuje się do herodotejskiej wizji konfliktu Wschodu i Zachodu, aby namalować jego epicką panoramę poczynając od porwań Iony i Europy, poprzez Medeę, Heraklesa i Amazonki i wojnç trojańską, aż do ostatecznego podboju Azji przez Aleksandra ${ }^{60}$. Wspomnieć wypada w tym kontekście również urzekająco piękną i sugestywną IV Eklogę Wergilusza zapowiadającą narodziny małego chłopca i nadejście złotego wieku ${ }^{61}$. Porównanie bogactwa orientalnej literatury profetycznej z podobnymi dziełami literatur Zachodu prowadzi do wniosku, ze ta dziedzina twórczości była domeną kultur irańskich, semickich i afrykańskich.

Obszerny ancks klasycznej teorii walki Azji z Europą stanowią stereotypowe charakterystyki ludzi Orientu, ich obyczajów, religii i mentalności. Wybieramy tu zaledwie parę przykładów spośród wielu. Przygotowując scenę dla zbrojnego konfliktu pomiędzy Septymiuszem Sewerem i Nigrem Herodian zestawia okrucieństwo, siłę i odwagę ludzi północy ze słabością i zniewieścialością Syryjczyków, żołnierzy Nigra ${ }^{62}$. Tak więc Herodian powta-

1929; J. Bidez - F. Cumont, Les mages hellénisés: Zoroastre, Ostanès et Hystaspe d'après la tradition grecque, Paris 1938; G. Widengren, Leitende Ideen und Quellen der iranischen Apokalyptik, w: Apocalypticism in the Mediterranean World and the Near East, ed. D. Hellholm, Tübingen 1983, 77-162.

57 Por. Suetonius, Augustus 31, 3.

58 Por. De morle Peregrini 29.

59 Plutarchus, Alexander 17, 2; Kallistenes powoluje się na proroctwa Sybilli dotyczące Aleksandra, zob. Strabon, Geografica hypomnemata XVII 1, 13.

6) Por. Alexandra 1253-1450. Najlepszym wprowadzeniem do calości problematyki Aleksand$r y$ pozostaje nadal: K. Ziegler, Lycophron (8), RE XIII 2316-2381; uzupełnienie: S. Josifovič, Lykophron, RE Suppl. XI 888-930; najlepsze wydanie tekstu ze scholiami: E. Sheer, Lycophronis Alexandra, vol. 1-2, Berlin 1881-1908; S. West, Lycophron's Alexandra: 'Hindsight as foresight makes no sense', w: M. Depew - D. Obbink (ed.), Matrices of genre: Authors, Canons and Society, Harvard 2000, 153-166; tenże, Lycophron italicised, „Journal of Hellenic Studies" 104 (1984) 127-151; G. Shade, Lycophrons 'Odyssee': Alexandra 648-819, Berlin 1999.

${ }^{61}$ Por. R.G. Nisbet, Virgil's Fourth Eclogue: Easterners and Westerners, „Bulletin of the Institute of Classical Studies of the University of London" 25 (1978) 59-78.

${ }^{62}$ Por. Historiae II 9, 11; 11 7, 9-10. 
rza charakterystykę Syryjczyków, przedstawioną kiedyś przez Posejdoniosa $z$ Apamei ${ }^{63}$, rozpoznawalną również w Liwiuszowym opisie zdemoralizowanych wojsk perskich Dariusza III ${ }^{64}$, i jeszcze raz powtórzoną przez Prokopiusza z Cezarei w mowie arabskiego szejka Alomundarosa, skierowanej do perskiego króla Kabadesa ${ }^{65}$. Chcąc przedstawić charakter Chosroesa 1 Prokopiusz z Cezarei odwołuje się do znanego już Herodianowi stereotypu człowieka Wschodu, który posiadł sztukę ukrywania swoich rzeczywistych intencji za zasłoną obłudnego języka i pozornych działań, mistrza podstępu i obłudy ${ }^{66}$. Podobnie Kasjusz Dion charakteryzując Karakallę napisze, że odziedziczył on po swoich przodkach to co najgorsze: afrykański prymitywizm i dzikość, oraz syryjską przebiegłość ${ }^{67}$. Herodian z prawdziwą odrazą przedstawia obyczaje, stroje, kosmetykę, barbarzyńskie praktyki religijne i seksualne dewiacje Heliogabala, zasiadającego na tronie rzymskim potomka arabskiej rodziny kapłańskiej z Emezy ${ }^{68}$. Jako dzikich i nieujarzmionych barbarzyńców, żyjących tylko w namiotach i przemierzających na swoich koniach i wielbłądach rozległe ziemie Azji Zachodniej i północno-wschodniej Afryki, przedstawia Arabów Ammianus Marcellinus ${ }^{69}$. Można by się dziwić przekazanej w Historiach Tacyta charakterystyce religii żydowskiej jako ponurego zabobonu, gdyby nie fakt, że znana jest nam ona $z$ wielu innych dzieł wpływowych uczonych, retorów i historyków greckich epoki hellenistyczno-rzymskiej, z pism Molona, Apiona, Diodora czy Posejdoniosa z Apamei ${ }^{70}$. Szyderstwa $z$ egipskiego kultu zwierząt stanowią jeszcze jeden locus communis literatur klasycznych składający się na grecko-rzymski wizerunek Orientu ${ }^{71}$; powraca $w$ nich obraz fanatycznych i prymitywnych Egip$\operatorname{cjan}^{72}$. Lukiana $z$ Samosate razi orientalny fanatyzm Frygów (Alexander), chrześcijan i brahmanów (De morte Peregrini). Kolejnym elementem tworzącym ten wizerunek jest charakterystyka języków orientalnych, egipskiego, perskiego, syryjskiego czy hebrajskiego, których barbarzyńskie, bełkotliwe

${ }^{63}$ Por. Athenaeus, Deipnospophistae V 46.

${ }^{64}$ Por. Ab urbe condita IX 18.

65 Por. Historia bellorum. Persica I 17, 37.

${ }^{66}$ Por. tamże II 9, 8; Septymiusz Sewer u Herodiana, Historiae II 9, 13; szejk Abgaros u Plutarcha, Crassus 21.

${ }^{67}$ Por. Historia Romana LXXVIII 6, 1a, ed. V. Boissevain.

68 Por. Historiae V 5, 3-6, 10.

69 Por. Res gestae XIV 4, 1-7.

${ }^{70}$ Por. M. Stern (ed.), Greek and Latin Authors on Jews and Judaism, I-II, Leiden 1974, 1980, Suppl. Jerozolima.

71 Por. K.A.D. Smelik - E. Hemelrijk, 'Who knows not what monsters demented Egypt worships'? Opinions on Egyptian animal worship in antiquity as part of the ancient conception of Egypt, ANRW II 17. 4, ss. 1852-2000.

${ }_{72}$ Por. Juvenalis, Satira XV; list Hadriana w Historia Augusta , Quadraginta tyrannorum” 7, 4. $8,10$. 
brzmienie razi uszy wykształconych Greków ${ }^{73}$. Jeśli do tego wszystkiego dodamy jeszcze motyw, który zgodnie $z$ tradycjami polskiej literatury moglibyśmy zatytułować „pocałowaniem wszczepiłem w duszę jad co was będzie pożerać...", a więc motyw zarazy, który pojawia się w związku $z$ wojną partyjską w czasach Marka Aureliusza, kiedy to w splądrowanej świątyni Bela zołnierze według różnych wersji, albo rozbijają w poszukiwaniu skarbów jakąś szkatułkę ${ }^{74}$, albo otwierają jakąś podziemną komnatę ${ }^{75}, \mathrm{z}$ której wypełza dżuma, i jeśli dalej przypomnimy sny z bóstwami orientalnymi, które według wiedzy Artemidora zapowiadają nieszczęścia lub śmierć ${ }^{76}$, to możemy odnieść wrażenie, że kulturę, która obrazy te wydała, przenikał jakiś szczególny lęk, jakiś horror Orientis, nieobcy również współczesnej masowej kulturze Zachodu. Wschód tymczasem pozostawał nieprzenikniony za zasłoną swoich języków, religii i obyczajowości.

\section{RELIGIJNE INTERPRETACJE KONFLIKTU W EPOCE PÓŹNEGO ANTYKU}

W literaturze greckiej późnego antyku pojawiają się nowe elementy związane z chrystianizacją świata rzymskiego. Prokopiusz z Cezarei opisuje kampanię wojenną Chosroesa I z 544 r. w kategoriach wojny religijnej:

„Chosroes nie skierował swojego ataku ani przeciw Justynianowi, cesarzowi Rzymian, ani żadnemu innemu człowiekowi, lecz wyłącznie przeciw bogu, któremu oddają cześć chrześcijanie" 77 .

Odwrót spod murów Edessy magowie perscy odczuli jako upokorzenie ze strony Boga chrześcijan. Zdobycie Edessy stało się więc dla Chosroesa I sprawą osobistej ambicji i nabrało wymiaru rywalizacji religijnej. Otóż Edesseńczycy swoją pewność czerpali z obietnicy zawartej w korespondencji króla Edessy Abgara Czarnego z Chrystusem. W ostatnich słowach sławnego apokryfu Chrystus odwdzięczając się za ofiarowywaną mu gościnę miał obiecać Edesseńczykom, że miasto ich nigdy nie wpadnie w ręce barbarzyńców. Korespondencję tę znamy $\mathrm{z}$ zachowanych $\mathrm{w}$ języku syryjskim apokryficznych

${ }^{73}$ Por. Lucianus, Alexander 13, 51 (syryjski, hebrajski); Deorum concilium 9, 14 (perski i inne języki Orientu); Dialogi meretricium 4, 5; luppiter tragoedus 13; J. Bompaire, Lucien écrivain. Imitation et creation, Paris 1958, 151.

74 Por. Historia Augusta, Verus 8, 1-4.

75 Por. Ammianus Marcellinus, Res gestae XXIII 6, 24.

76 Por. Onirocritica I 37; II 12; II 39, ed. R. Pack, Leipzig 1963.

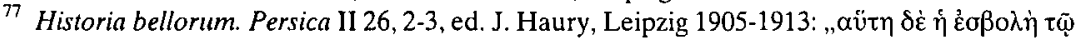

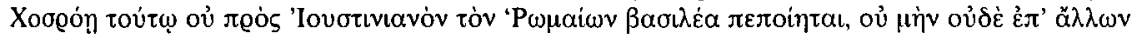

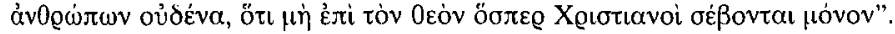


Nauk Apostoła Addaja ${ }^{78}$. Prokopiusz przedstawia treść listu w dużym skrócie, dodając, że historycy tych czasów nic nie wspominają o żadnej obietnicy ${ }^{79}$. Ostrożność okazała się tym razem uzasadniona. Edessa wpadła w ręce perskie niedługo po śmierci Prokopiusza. Wojna Justyniana $\mathrm{z}$ Chosroesem I ukazuje się Prokopiuszowi jako wojna uniwersalna, której istota sięga źródeł kosmicznego porządku. Poprzedziło ją pojawienie się na niebie dużej komety, której początek zwracał się w stronę wschodu, koniec zaś w stronę zachodu. Zapowiadając dziejowe nieszczęścia kometa ukazała się na tle znaku Łucznika. Jej kształt jednym kojarzył się z mieczem, jakby w zgodzie $\mathrm{z}$ wizjami autorów proroctw sybillińskich, innym przypominał brodę $e^{80}$. Nietrudno odczytać symbolikę tego budzącego lęk astronomicznego zjawiska. Zarówno „łucznik” jak i ,broda” kojarzyły się Grekom z Persami. Element cudowności pojawia się również w relacji ataku Chosroesa I na Apamę̨ syryjską. W godzinach zagrożenia kapłani odprawiali procesję z relikwiami drzewa Krzyża Świętego, najświętszą relikwią Apamei. Prokopiusz opisuje cud światla, który dokonał się na oczach wiernych. Chosroes po wzięciu okupu wycofuje się spod murów miasta. Prokopiusz nie miał wątpliwości, ze Apamea ocalała w sposób cudowny ${ }^{81}$.

W Persikach Prokopiusza ujawnia się nie tylko nowa chrześcijańska wrazliwość, ale chyba również narastającc wśród Greków orientalnych poczucie beznadziejności sytuacji. Jerzy Pizydes nazwie Chosroesa II wprost „Antychrystem" "82. Motyw Lignum Crucis prowadzi nas już do epoki wojen średniowiecza $\mathrm{z}$ islamem. W zwycięskiej bitwie pod Ain Anżar rycerstwo chrześcijańskie wyruszy do ataku z relikwiami Krzyża Świętego. Sytuacja ta powtórzy się w pamiętnej bitwic pod Hattin (1187), ale tym razem Lignum Crucis dostanie się znowu w ręce mahometan.

${ }^{78}$ Por. G. Philips, The Doctrine of Addai, the Apostle, London 1876; Die Lehre des Apostels Addai, w: C. Brockelmann, Syrische Grammatik mit Paradignen, Literatur, Chrestomathe und Glossar, Leipzig 1960; posiadamy poiski przekład z syryjskiego W. Witakowskiego ze wstępem i komentarzem: Natka Apostoła Addaja, STV 22 (1984) z. 2, 181-213; M. Starowieyski, Apokry. ficzna korespondencja króla Abgara z Chrystusem, thum. z greckiego, STV 15 (1977) z. 2, 177-200: J. Ortiz de Urbina, Patrologia Syriaca, Romae 1965, 44; C. Brockelmann, w: Geschichte der christlichen Literaturen des Orients, Leipzig 1909 (repr.1972), 7.

${ }^{79}$ Por. Historia bellorum. Persica II 12, 25-26.

${ }^{80)}$ Por. tamże II 4, 1-2.

81 Por. tamże II 9, 14nn.

82 Por. D. Brodka, Das Bild des Perserkönigs Chosroes I in den "Bella" des Prokopios von Kaisareia, „Classica Cracoviensia” 4 (1998) 115-124, spec. 123n; W. Speyer, Gottesfeind, w: RACh XI 1981, spec. 1035. Dr D. Brodce serdecznie dziękuję za konsultacje odnośnie epoki późnego antyku ora\% za cenne informacje bibliograficzne. 


\section{KONFLIKT WSCHODU I ZACHODU JAKO PRZEJAW MITOLOGIZACJI HISTORII}

$\mathrm{Na}$ koniec parę refleksji dotyczących ograniczeń teorii wiecznej wojny Wschodu i Zachodu, którą Herodot uczynił jednym $z$ najistotniejszych elementów swojej filozofii dziejów. Czy teoria ta, a może raczej zbiór rozrzuconych po literaturze greckiej refleksji na temat wojen wschodnich, miała związek z rzeczywistością historyczną? Czy nie byla to jedynie stworzona w kręgach ludzi wykształconych literacka fikcja, która przetrwała długie stulecia mimo zmieniającej się sytuacji historycznej? Z doświadczeń ostatniego stulecia wiemy, że teorie mogą z całą mocą kształtować rzeczywistość wbrew zdawałoby się oczywistej wiedzy historycznej, gospodarczej czy psychologicznej, a nawet wbrew zdrowemu rozsądkowi. Nie chciałbym przekonywać do prawdziwości teorii Herodota, i zamieniać, jakby to powiedział R. MacMullen, historycznego doświadczenia ludzi w długie, uczenie brzmiące zdania ${ }^{83}$. Czy więc konflikt Europy i Azji istniał w rzeczywistości? Konflikt grecko-perski czasów Herodota, zmitologizowany w literaturze greckiej, z perspektywy perskiej był jednym z granicznych konfliktów wielkiego imperium. Był jednak o tyle ważny, że wyznaczył jego zachodnią granicę wzrostu. Podobnie rzecz się miała $\mathrm{z}$ innymi konfliktami monarchii Cyrusa Wielkiego: na północy z Massagetami, na wschodzie $\mathrm{z}$ mieszkańcami doliny Indusu. Ten ostatni konflikt można by również rozpatrywać jako konflikt Wschodu i Zachodu. Analogicznie można by przedstawić trwały i nierozwiązywalny konflikt ludów irańskich z ludami środkowej Azji, które historycy greccy nazywają Hunami, Massagetami, czy Scytami. Konflikt ten możemy określić podobnie, posługując się tymi samymi kryteriami, jako konflikt Północy i Południa, co nawet lepiej brzmi dla współczesnych uszu. Rzym odziedziczył opanowany przez Macedończyków obszar wschodniośródziemnomorski, a wraz z nim endemiczny konflikt $\mathrm{z}$ władcami Iranu. Tak rozpoczynają się długie zmagania pomiędzy dwoma imperiami o kontrolę nad tym obszarem. Ciekawe, że jakby na przekór teorii wiecznej walki Wschodu z Zachodem oba imperia upadną od uderzeń sąsiada i sojusznika z Południa, Arabów. Stanowi to jeszcze jeden dowód na to, że istotą wojen nie jest jakaś stworzona przez historyków geografia, lecz, jak chciał Tukidydes, koncentracja siły militarnej, która nieuchronnie prowadzi do imperializmu ${ }^{84}$. Konfrontacja Persji z Macedonią i Rzymem nie wynikała więc z jakiegoś modelu kontynentalnego czy kulturowego, lecz z koncentracji siły w tym samym czasie historycznym na Bałkanach, potem w Italii, i w Iranie. C. Jaspers w swojej znanej książce

${ }^{83}$ Por. R. MacMullen, Enemies of the Roman Order. Treason, Unrest, und Alienation in the Empire, Cambridge Mass. 1966, 207.

${ }^{84}$ Por. H. Immerwahr, Thucydides, w: Cambridge History of Classical Literature, Cambridge $1985,441-456$, spec. 452. 
Vom Ursprung und Ziel der Geschichte ${ }^{85}$ zauważa, że z jakichś względów w tym samym czasie wzdłuż strefy podzwrotnikowej na północnej półkuli, niezależnie od siebie, wyrosły w Ameryce Środkowej, w Europie na Bałkanach, w Anatolii i na Bliskim Wschodzie, w Iranie i w Chinach zaawansowane cywilizacje. Tak więc konflikt Wschód-Zachód był jakby wpisany w geografię tego świata. Trzeba jednak dodać, że cywilizacje te nieustannie zmagały się z zagrożeniami pochodzącymi od kultur zwanych chętnie peryferycznymi, kultur z Północy i Południa. Swoją szczególną rangę w literaturze grecko-rzymskiej konflikt z Persją zawdzięcza temu, że była to konfrontacja z dziedzicami prastarych cywilizacji Orientu. Historiografia grecka spycha w cień endemiczny konflikt z Berberami, ludami Etiopii i Sudanu, czy pustyń Arabii. Mieszkańcy tych krain nie zasługiwali na uwagę podobną tej którą poświęcano Persom. Germania Tacyta jest jednak dowodem, że teoria walki ze Wschodem, była tylko jednym $z$ elementów myślenia historycznego polityków, wojskowych i uczonych grecko-rzymskich. Nie był to więc konflikt światów, Europy i Azji, lecz zuniwersalizowany w kulturowych ramach lokalnej tradycji regionalny konflikt dwóch potęg - śródziemnomorskiej i irańskiej, ogniskujący się w rejonie Bliskiego Wschodu, a więc oczywiście w rejonie bardzo ważnym ze względów strategicznych i gospodarczych.

\section{PRZEMILCZANE WOJNY W GRECKIEJ HISTORIOGRAFII}

Dochodzimy w tym miejscu do zagadnienia przemilczanych wojen historiografii klasycznej. Jest rzeczą zadziwiająca, jak mało wiemy o długiej i krwawej wojnie w Palestynie w latach $132-135$ po Chrystusie. Kasjusz Dion opowiada nam o walkach w podziemnych tunelach, o zawziętości powstańców, o okrutnej wojnie połącżonej z eksterminacją ludności cywilnej ${ }^{86}$. Ciekawe, że pamięć o tej wojnie ocalił w swoim Senniku Artemidor z Efezu, zwany Daldianos, zapisując koszmar, jaki nawiedzał jednego $z$ oficerów rzymskich długie lata po wojnie. Zlany zimnym potem budził się po nocach widząc miecz

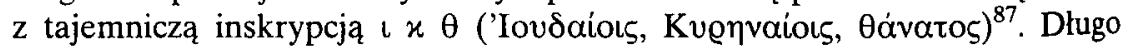
powątpiewano w istnienie jakiegoś Bar Kochby, którego imię ocalił skrupulatny i dokładny badacz przeszłości Euzebiusz z Cezarei ${ }^{88}$. Nie chciano mu wierzyć, choć to przecież tylko on spośród historyków starożytnych wykorzystał skarby zgromadzone w zbiorach bibliotecznych palestyńskiej Cezarei. I dopiero ciekawość archeologów penetrujących groty Pustyni Judzkiej po-

\footnotetext{
85 Zürich 1949.

86 Por. Historia Romana LXIX 12-14; Y. Yadin, Bar-Kokhba, Jerozolima 1971; P. Schäfer, Der Bar Kokhba-Aufstand, Tübingen 1981.

87 Por. Onirocritica IV 24, ed. R. Pack, Leipzig 1963.

${ }^{88}$ Por. HE IV 6, 2.
} 
twierdziła istnienie znanego tylko Euzebiuszowi powstańczego dowódcy. W ukrytej wśród skał Nahal Deragot jaskini Mura'baat znaleziono resztki jednego $\mathrm{z}$ jego archiwów. Ta chęć spuszczenia zasłony milczenia i zapomnienia na historię antygreckich i antyrzymskich buntów rodzimej ludności na Wschodzie jest cechą źródeł klasycznych w epoce hellenistyczno-rzymskiej. Zaledwie parę zdań poświęca Polibiusz długiej i krwawej wojnie domowej w Egipcie, choć jej dzieje są kluczem do zrozumienia stopniowej i nieodwracalnej degradacji jednej $z$ najbogatszych monarchii świata grecko-rzymskie$\mathrm{go}^{89}$. Omalże zapomniano również o powstaniu egipskich Bukolów, po którym pozostało jedno zdanie w Historia Augusta, napisanej około 150 lat później $^{90}$. A przecież, żeby stłumić ten długotrwały zbrojny bunt, trzeba było legionów Awidiusza Kasjusza; po dziś dzień brak Bukolów w leksykonach klasycznych. Damnatio memoriae historiografii klasycznej ma nadal siłę obowiązujacą. I jeżeli wspomnienie jednej czy drugiej wojny o wolność narodów Wschodu, żyjących pod panowaniem macedońskim czy rzymskim ocalało w integralnym kształcie, to zawdzięczamy ten fakt piszącym po grecku autorom pochodzenia orientalnego, jak Józef Flawiusz czy autorzy Ksiag Machabejskich. Ten pierwszy, odrzucony przez swoich jako renegat, ci drudzy wykreśleni z rejestru Ksiąg Świętych przez synod w Jamnia, zostali ocaleni przez chrześcijan, którzy szczęśliwie posługiwali się greckim tłumaczeniem aleksandryjskim jako Pismem świętym Kościoła ${ }^{91}$. Fakty te wpłynęły na naszą selektywną znajomość historii stosunków grecko-orientalnych. Symbolem oporu Wschodu w tradycji Zachodu pozostają powstania Machabeuszy i zniszczenie Świątyni Jerozolimskiej w 70 r. po Chrystusie. Tymczasem w epoce wspólczesnej Machabeuszom, Grecy i Macedończycy zmagali się również z innymi ludami Azji Zachodniej: Elamitami, Frygami, Karami, Partami, Cylicyjczykami, Egipcjanami czy Nubijczykami ${ }^{92}$. Nie umniejszając znaczenia ich walki dla historii Żydów, Machabeusze mogli poszczycić się rozbiciem jakiegoś oddziału greckiego. W walce $z$ Elamitami, również o świątynię, a więc w podobnym konflikcie na tle religijnym, zginął sam Antioch III (187 r. prz. Chrystusem). Ale to właśnie partyzantka Machabeuszy stała się za pośrednictwem chrześcijan jednym z mitów Zachodu, podczas gdy Syryjczycy, Arabowie czy Partowie, którzy nie tylko powstrzymywali skutecznie pochód wojsk rzymskich $w$ głąb Bliskiego i Środkowego Wschodu, ale i potrafili najeźdźcom zadawać dotkliwe klęski, pozostali w cieniu popularnej wersji historii Zachodu.

${ }^{89}$ Por. Historiae V 105.

${ }^{40}$ Por. Historia Augusta. Pius 5, 5.

91 Por. W. Speyer, Büchervernichtung und Zensur des Geistes bei Heiden, Juden und Christen, München 1981, 116 i 161.

${ }^{22}$ Panoramę tych konfliktów maluje w swojej fascynującej książce S. Eddy, The King is Dead. Studies in the Near Eastern Resistance to Hellenism 334-31 BC, Lincoln 1961. 


\section{UTRACONE DZIEDZICTWO GRECKIEJ LITERATURY ORIENTALNEJ}

Nie znajdujemy również refleksji na temat przyczyn utraty zdobyczy Aleksandra na Wschodzie oraz niezdolności do przejęcia dziedzictwa Seleukidów przez Rzym. Jest rzeczą zagadkową, że Antioch III wyruszywszy znad Orontesu, w ciągu kilku lat przeszedł przez Iran, doszedł do stóp Hindukuszu, a następnie przez tereny współczesnego Afganistanu i ziemie Elamu dotarł do Zatoki Perskiej, którą przekroczył, aby zakończyć swoją wyprawę tryumfem w Babilonie. Podobnych wyczynów dokonał również Eukratidas, generał Antiocha IV Epifanesa (175-164 prz. Chrystusem) ${ }^{93}$. A przecież Posejdonios z Apamei, a w ślad za nim i Liwiusz, przedstawiają syryjskich poddanych Seleukidów jako ludzi zniewieściałych i słabych, budzących pogardę urodzonych żołnierzy, za jakich mieli się Rzymianie ${ }^{94}$. Rodzi się więc pytanic, dlaczego Rzymianic nie byli w stanie przejąć dziedzictwa Seleukidów, mimo swojej wyższości militarnej i tężyzny fizycznej. Tego pytania historycy epoki cesarstwa sobie nie zadawali, a przynajmniej nie robili tego głośno. Czy na pewno sobie nie zadawali tego pytania, nie wiemy. Nie znajdujemy również refleksji nad dalekimi skutkami sławionego zwycięstwa Rzymu nad Antiochem III, skutkami, które stały się widocznc dla Rzymian najpóźniej w okresie, gdy do Syrii wkroczył Pompejusz (64 r. prz. Chrystusem). Klęska Antiocha III w latach 190189 prz. Chr. zadecydowała o bezpowrotnej utracie wpływów greckich na ogromnych obszarach Bliskiego i Środkowego Wschodu. Niszcząc flotę Seleukidów i dokonując rozbrojenia ich armii (które obejmowało również okrutne okaleczenie słoni), podciçto samą możliwość kontrolowania tych obszarów przez orientalnych Greków. Bitwa z Partami w północnym Iranie w roku 129 prz. Chr., w której ginie Antioch VII Sidetes, stanowi zamknięcie pewnej epoki historycznej. Był to prawdziwy koniec imperium Aleksandra, a więc i znaczącej obecności Greków na obszarach na wschód od Eufratu. Diodor Sycylijski zachował nam opis wydarzeń 129 r. na Wschodzie ${ }^{95}$. Ten zazwyczaj oszczędny i rzeczowy historyk opisuje przejmującą żałobę, jaka dotknęła każdy dom w Antiochii, oraz powszechny i zbiorowy lament nad polcgłymi. Jednak żolnierzy poległych w przegranych bitwach nie wspomina się chętnie w szkołach. Tak więc historiografia grecko-rzymska, a wraz $\mathrm{z}$ nią cała literatura klasyczna, uznała za kluczową inną datę tej epoki, rok 146, rok upadku Kartaginy i Koryntu. W istocie nie była to data przełomowa. Losy bowiem Kartaginy

${ }^{93}$ Posiadamy monografię panowania Antiocha IV: O. Morkhølm, Antioch IV of Syria, Copenhagen 1966.

94 S. Sherwin-White i A. Kuhrt (From Samarkhand to Sardis. A New Approach to the Seleucid Empire, London 1993) podjęły próbę odsłonięcia rzeczywistego obrazu monarchii Seleukidów spod nawarstwień rzymskiej propagandy, fałszywych stereotypów i deformacji.

${ }^{95}$ Por. Bibliotheca XXXIV-XXXV 17, ed. C. Fisher et alii, Leipzig 1888-1906. 
i Koryntu, jak i całego obszaru wschodniośródziemnomorskiego zadecydowały się już wcześniej, na przelomie IIU/II wieku prz. Chr. w okresie wojen z Hannibalem, Filipem V i Antiochem III.

Kolejnym nieudanym wyprawom Rzymian w gląb Bliskiego Wschodu patronował mit Aleksandra. Można odnieść wrażenie, że mit ten stał się jakąś fatalną pułapką myślenia historycznego, a z nim razem i politycznego Greków i Rzymian epoki cesarstwa. Rzymianie doznali wiclu klęsk, a ich zwyciçstwa okazywały się efemeryczne. Czas mijał, sytuacja ulegała zmianie, a greckorzymskiemu myśleniu o Wschodzie patronowały nieustannie dwie legendy: jedna stworzona przez Herodota, druga przez Aleksandra. Skąd ten brak nowej refleksji? Jakiś wpływ miała na to głęboka alienacja, autoizolacja i greckie poczucie wyższości w stosunku do barbarzyńców, ale również chyba brak istotnego wplywu na bieg polityki państwowej wobec scentralizowanego systemu rządów zc strony ludzi, którzy zagadnienia Wschodu rozumieli lepiej. Wielką i niepowetowaną szkodę greckiej myśli historycznej przyniosło zniszczenie u schyłku epoki hellenistycznej ośrodków alternatywnych, których istnienie zawsze odgrywa w kulturze rolę inspirującą. Korneliusz Nepos wspomina Silenusa i Sosylosa, greckich antyrzymskich historyków skupionych wokól Hannibala ${ }^{96}$. Podobne, niezależne od Rzymu, środowisko otaczało Mitrydatesa VI (107-63 prz. Chrystusem) ${ }^{97}$. Inne gromadziło się wokół dworu w Antiochii. Środowiska te w sposób oczywisty były predestynowane do odegrania szczególncj roli w analizic sytuacji w Azji Zachodnicj swoich czasów. Historycy podzielili jednak los swoich panów. Zostali zniszczeni wraz ze swoim dorobkiem. Zwycięzcy nie zdawali sobie sprawy z dalekosiężnych skutków tego bezmyślnego niszczycielstwa intelektualnego dorobku swoich przeciwników. Po Herodocie i Aleksandrze zwyciężył wizerunek barbarzyńcy mówiącego bełkotliwym żargonem, kulturowy model autoizolacji, zwyciężył militaryzm i mentalność kolonialna, dla których nie dopuszczano alternatywy. Jedną $z$ podstawowych barier dla stworzenia głębszej wiedzy o narodach Bliskiego Wschodu w epoce cesarstwa byla nieznajomość języków orientalnych wśród intelektualistów greckich i rzymskich. Bariera ta była tak silna, że nawet chrześcijaństwo ze swoim uniwersalnym posłaniem, które początkowo zaowocowało fascynującym odrodzeniem literatur narodowych na Wschodzie, etiopskiej, koptyjskiej, syryjskiej czy ormiańskiej, poddało się ostatecznie podziałom na kościoły o tradycji greckiej i orientalnej. Podziały zapadły więc wzdłuż barier językowych. Nie wszystkiemu oczywiście winni są politycy i historycy rzymscy.

${ }^{96}$ Por. De viris illustribus. Hannibal $13,3$.

${ }^{97}$ Por. H. Fuchs, Der geistige Widerstand gegen Rom in der antiken Welt, Berlin 1938 (repr.1964); J. Deininger, Der politische Widerstand gegen Rom in Griechenland 217-86 v. Chr., Berlin - New York 1971; analogiczne antyrzymskie środowisko skupione było wokół Zenobii: F. Millar, Paul of Samosata, Zenobia and Alurelian: the Church, Local Culture and Political Allegiance in Third Century Syria, ,Journal of Roman Studies” 61 (1971) 1-17. 
W cieniu akademickicj historiografii, której przez stulecia w opisie konfliktów na Wschodzie patronowali Herodot i historycy Aleksandra Wielkiego, pozostawały rzeczywiste i istotne problemy w stosunkach Wschodu i Zachodu, jak choćby właśnie trudne do pokonania bariery językowe, a wraz z nimi odrębność irańskiej, semickiej i afrykańskiej tradycji kulturowej. Tak więc nikt nie był w stanie, lub nie chciał, odpowiedzieć, dlaczego Aleksandrowi, Antiochowi III, Eukratidasowi, czy greckim królom baktryjskim, udało się dokonać tego, czego dokonali na Wschodzie w znaczeniu militarnym, politycznym i kulturowym, i zarazem odpowiedzieć dlaczego innym nie udało się ich sukcesów powtórzyć, choć zdawałoby się, że dysponowali lepszymi środkami. Mam wrażenie, że pełnej odpowiedzi na te pytania potrafiliby udzielić, w jakiejś wyimaginowanej zbiorowej publikacji, Herodot, Aleksander Wielki i Antioch III.

Kiedy po uplywie długich stuleci czytamy wspaniałą prozę Erharta Kästnera, odnosimy wrażenie, że myśl historiozoficzna, która towarzyszyla Herodotowi podczas pisania jego. Historii, jest nadal żywa we współczesnej kulturze Zachodu. Jeden z bohaterów książki Die Stundentrommel vom heiligen Berg Athos, uciekinier z Trapezuntu, greckiej kolonii nad Morzem Czarnym, wspomina swoje rodzinne miasto, które opisał kiedyś Fallmerayer, i mówi: „Aber 1916 die Russen und 1922 die Türken: jetzt ist da nichts mehr zu beschreiben. Trapezunt ist eins unter dem Vielen, was das vorrückende Asien verschluckte" ${ }^{" 98}$. Refleksja jakże bliska każdemu, kto staje wśród imponujących ruin jednej z największych świątyń chrześcijaństwa, Bazyliki św. Jana w Efezie, w podcieniu naw opuszczonego już przed tysiącem lat martyrium św. Filipa w Hierapolis, budowli której architektura mimo postępującej ruiny, zachowuje coś z doskonałości klejnotu, czy w tylu innych miejscach Turcji, Syrii, Palestyny i Egiptu.

\title{
EAST-WEST CONFLICT IN THE GREEK LITERATURE FROM HERODOTUS TO PROCOPIUS OF CAESAREA
}

\author{
(Summary)
}

Herodotus presented the conflicts between Europe and Asia on both the mythological and historical level and made them one of the main structural and ideological components of his work. The idea of war against the Achaemenids interpreted as

98 E. Kästner, Stundentrommel vom heiligen Berg Athos, Frankfurt am Main 1995, 89. 
central to the Greek historical destiny returned time and again in the Greek letters, always blended with the symptomatic feeling of superiority and simplified standard view of the Orientals (Euripides, Xenophon of Athens, Plato, Isocrates). The efforts to unite the Greeks and Macedonians with the Orientals which were undertaken by Alexander the Great, found little understanding among the Greeks (Plutarch). His myth as a conqueror of Asia became an ideological trap of the Hellenic as well as Roman historical thinking (Cassius Dio). Renewed and unsuccessful efforts to follow Alexander's steps brought interesting literary testimonies shaped by collective experiences of the insuperable climate, the fear of the epidemics, and confrontation with cunning, cruel and elusive adversaries (Plutarch, Procopius of Caesarea). The Greek literary testimonies had their alter ego in the Eastern prophetic writings, which expressed hostility towards the Greeks and Romans and predicted a final victory for the East over the West (Oracula Sibyllina, The Oracle of the Potter, The Oracle of Hystaspes). In the Wars of Procopius of Caesarea a pessimistic, purely militarist view came to the surface. It said that the loyalty of the Orientals could be secured only through the use of military power. In that period we also observe a factor of religious inspiration in the war propaganda on both sides (Procopius of Caesarea, Georgios Pisides). 